\title{
Nola erabili azpiproduktuak eta hondakinak, propietate egokiak dituzten material jasangarriak garatzeko?
}

\author{
How can we use waste and by-products to develop \\ sustainable materials with specific functional properties? \\ Tania Garrido, Pedro Guerrero, Koro de la Caba*
}

BIOMAT Ikerketa Taldea. Ingeniaritza Kimikoa eta Ingurumenaren Saila. Gipuzkoako Ingeniaritza Eskola. Euskal Herriko Unibertsitatea (UPV/EHU)

Itsaso Leceta

BIOMAT Ikerketa Taldea. Matematika Aplikatua Saila. Gipuzkoako Ingeniaritza Eskola. Euskal Herriko Unibertsitatea (UPV/EHU)

*koro.delacaba@ehu.eus

DOI: 10.1387/ekaia.16160

Onartua: 2016-06-27

Laburpena: Ikerkuntza-lan askotan soluzio- eta konpresio- metodoak erabili ohi dira proteinetan oinarritutako konpositeak garatzeko. Hala ere, biokonposite berrien merkatu-bideragarritasuna, zuzen lotuta dago industria-aplikazio konbentzionalak garatzeko teknikekin, eta beraz, lan honetan estrusio eta injekziorako prozesatze-metodoak erabili dira, soja-proteinan oinarritutako biokonpositeak garatzeko. Bestalde, agarra erauzterakoan hondakin naturala lortzen da. Hondakin hau, biokonpositeen betegarri gisa erabili da. Betegarri honek, soja-proteinarekiko bateragarritasun ona erakutsi zuen, eta horrela biokonposite jasangarriagoak garatu dira. Biokonpositeen hesi-propietateak eta propietate optikoak egokiak izan ziren paketatze aplikazioetarako.

Hitz gakoak: azpiproduktuak, hondakinak, industria-manufaktura, material jasangarriak.

Abstract: Many studies have employed solution casting and compression moulding as processing methods to manufacture composites. Nevertheless, the commercial feasibility of soy protein-based biocomposites is directly related with the use of the techniques employed for processing synthetic polymers, such as extrusion and injection moulding. For that reason, those processing techniques were employed to develop soy protein based-biocomposites. Moreover, a natural waste obtained from the extraction of agar was used as a filler. This waste showed good compatibility with soy protein and contributed to the development of more sustainable materials. These biocomposites showed good barrier and optical properties for packaging applications.

Keywords: by-products, wastes, industrial manufacture, sustainable materials. 


\section{SARRERA}

20. mendean zehar industria petrokimikoan lortutako polimero sintetikoak ezinbestekoak izan dira bizitzaren arlo ugarietan eta horren ondorioz, beren erabilera izugarri handitu da. Hauek dira egun elikagaietarako ontziak edo plastikozko poltsak egiteko nagusiki erabiltzen diren polimeroak: polipropilenoa (PP), poliestirenoa (PS), polietilenoa (PE), polietilentereftalatoa (PET) eta polibinilkloruroa (PVC). Hauek prezio merkea, kalitate ona, edo prozesatzeko erraztasuna badute ere, ez dira biodegradagarriak eta iturri ezberriztagarrietatik datoz. Azken urteetan, hondakinen kudeaketa dela eta, ingurumen arazo larriak sortzen ari dira, batez ere kontsumo-ereduak sortutako hondakinen etengabeko hazkuntzaren ondorioz. 1. irudian ikus daiteke 2015. urteko plastikoen ekoizpena 311 MT -koa izan zela, baina soilik \% 14a bildu zen birziklatzeko [1]. Hala ere, geroz eta ingurumenarekiko ardura gehiago dago, ingurugiro-legediak geroz eta zorrotzagoak direlarik. Beraz, plastikoekin zerikusia duten hondakinen arazoari aurre egiteko asmoz, bultzada handia eman zaio jatorri berriztagarri eta izaera biodegradagarria duten materialen ekoizpenari, beti ere ingurumenerako bide lagungarriak eta ekonomikoki bideragarriak aukeratuz. Aipaturiko material hauen artean daude hain zuzen baliabide naturaletatik sortutako polimero biodegradagarriak, hau da, biopolimeroak.

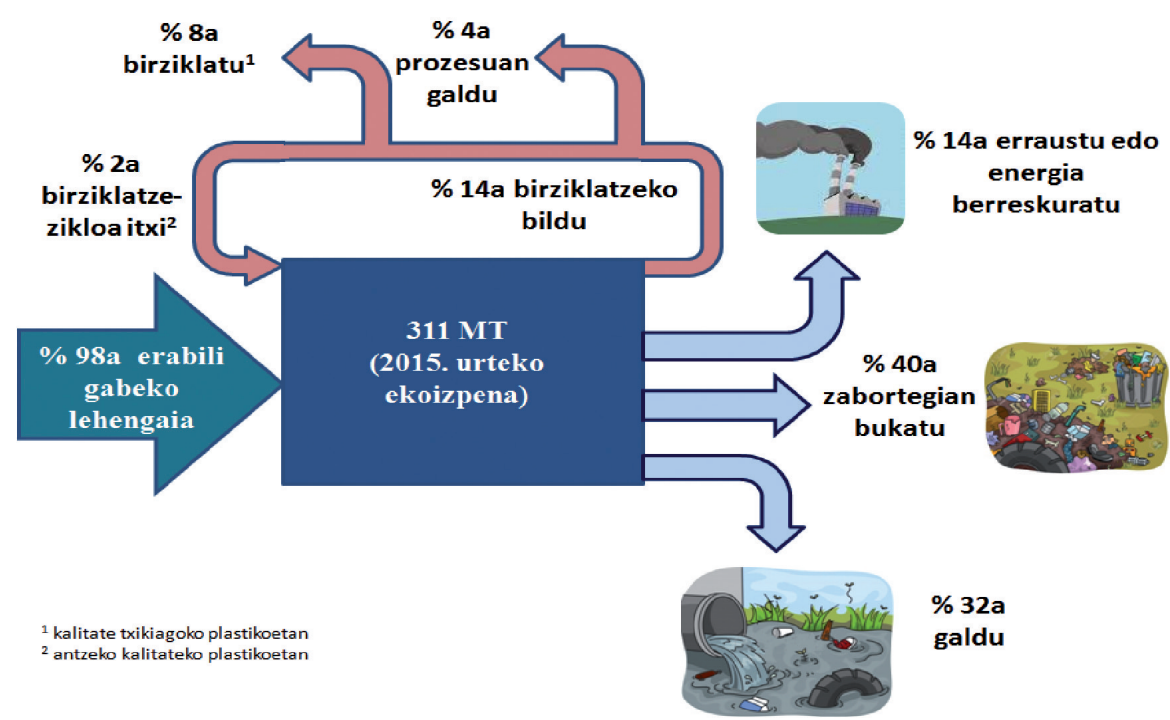

1. irudia. 2015. urteko plastikoen ekoizpena eta birziklatze-datuak. Iturria: The Global Risk Report, 2016. 


\section{NONDIK LORTU BIOPOLIMEROAK?}

Biopolimeroak dira jatorri ezberriztagarriko polimeroak ordezkatzeko aukerarik hedatuena, propietate egokiak dituztelako ontzi eta paketatze eremuko aplikazioetan: biodegradagarritasuna, erabilgarritasuna, edo gasen aurkako hesi-propietateak, batik bat. 2. irudian ikus daitezke biopolimeroen zenbait jatorri, baina edonola biomasako iturri berriztagarrietatik lortutakoek, garrantzi handia hartu dute materialen zientzian. Polisakaridoak eta proteinak dira talde horren barruan lan honetan erabiltzeko aukeratutakoak. Hauek berriztagarriak, ugariak eta inguruneari kalterik ez egiteaz gain, biokonpositeak eratzeko gaitasun bikainak dituzte [2,3].

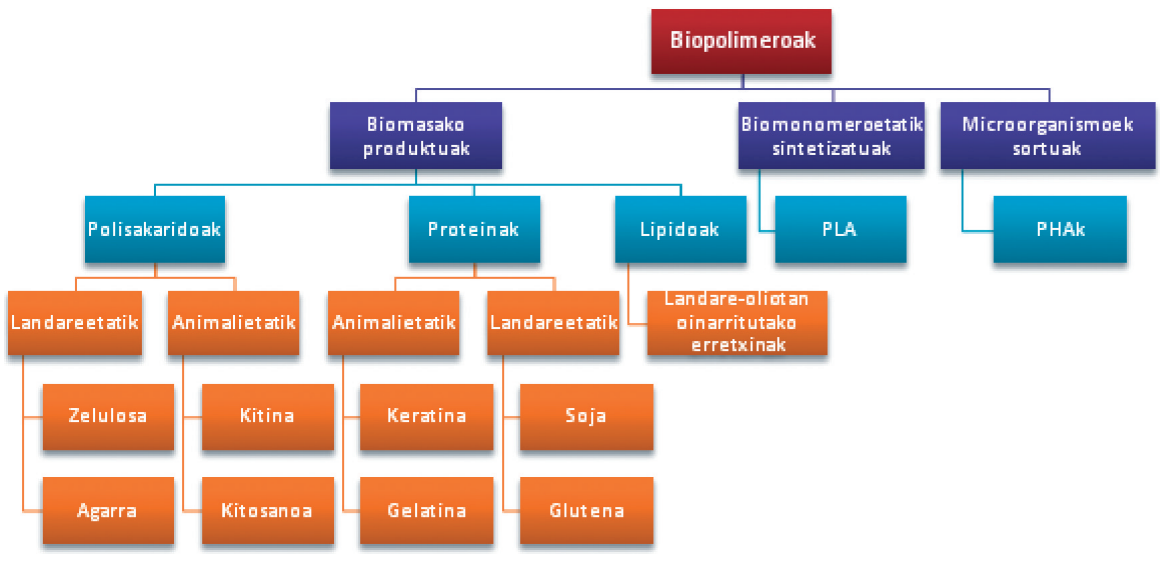

2. irudia. Zenbait jatorritatik lortutako biopolimeroak.

Proteinen artean, landare-proteinak daude eskuragarri barazkigintzan zein nekazaritza-industrian, azpiproduktu edo hondakin gisa; heteropolimeroak dira eta kateen arteko elkarrekintzak sortzeko aukera anitzak dituzte; izan ere talde funtzional desberdin ugariz osatuta daude.

Landare-proteinen artean, soja-proteina aukera ona da, naturako proteinarik merkeenetarikoa delako [4]. Soja-proteina soja-olioa ekoizterakoan lortzen da. Prozesu honetan, soja-irina azpiproduktu gisa eskuratzen da eta isolatutako soja-proteina bihur daiteke, erauzketa, proteinaren koagulazioa eta prezipitazioa eta esterilizazio prozesuen ondoren (3. irudia). Nekazaritzako azpiproduktuei balio erantsia ematen zaie soja-proteina isolatua erabiltzean.

Polisakaridoek ere badituzte filmak egitea bideratu dezaketen propietateak. Agarra etorkizun handiko produktua da, landareetatik lortutako polisakaridoen artean. Itsasoko alga gorritik erdietsi daiteke eta bere berriz- 


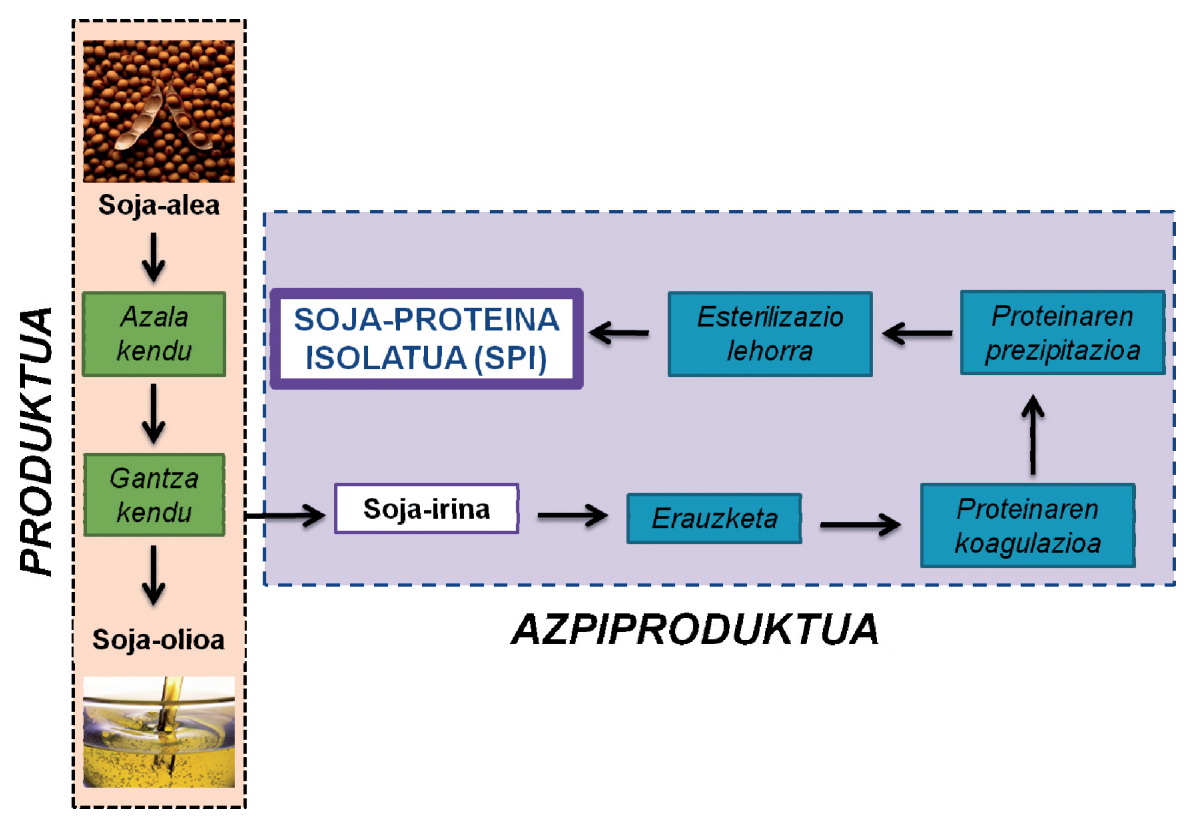

3. irudia. Soja-proteina isolatua (SPI) lortzeko prozesua.

tagarritasuna, biodegradagarritasuna eta gelifikazio-gaitasun handiagatik biokonpositeak garatzeko aukera interesgarria da [5]. Hala ere, agarraren erauzketa ez da hain merkea; horregatik, proposatu izan da soja-proteinan oinarritutako biokonpositeak prestatzeko alga-industrian sortutako hondakin naturala betegarri gisa erabiltzea. Agarraren erauzketan, alga gorria ur irakinean murgiltzen da eta lortutako soluzioa iragazketaren bidez bereizten da hondakinetik. Horren ondoren, hondakina lehortu egiten da eta etanola erabiliz, klorofila pigmentuak kentzen dira.

Amaitzeko, berriro lehortu, eho eta bahetu egiten da betegarri gisa erabiliko den hautsa lortzeko (4. irudia). Alga hondakina batez ere proteinaz eta lignina gabeko zelulosaz osatuta dago, baina agar hondarrak ere baditu. Hondakin horren erabilerak honako bi abantaila hauek izan ditzake: batetik, hondakina bera, era eraginkorrago batean erabil daiteke; bestetik, koste baxuagoko azpiproduktuak lor daitezke. Hain zuzen, ekonomiarako eta ingurumenerako onurak ekar ditzake konposite jasangarriago horien garapenak. 


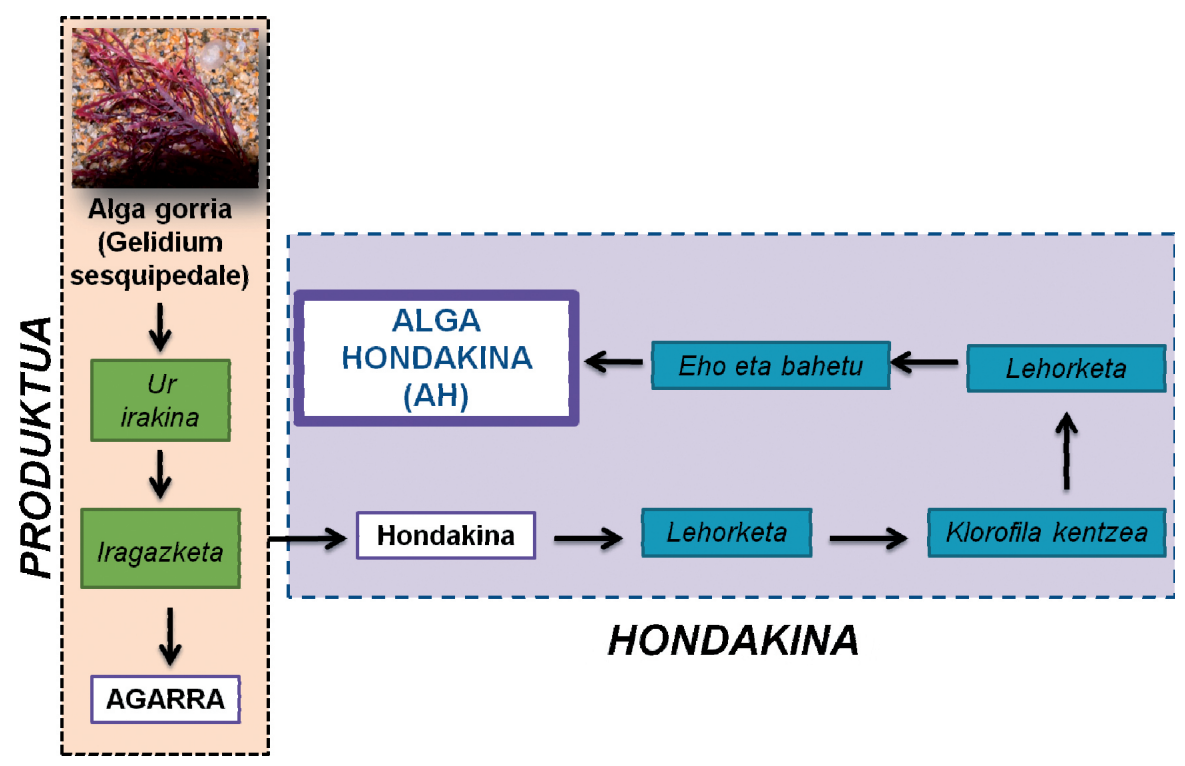

4. irudia. Alga hondakina (AH) lortzeko prozesua.

\section{NOLA GARATU MATERIAL JASANGARRIAK?}

Soja-proteinan oinarritutako biopolimeroek ahalmena dute polimero sintetikoak ordezkatzeko, baina hala ere eragozpen batzuk badituzte haien egitura kimikoarengatik, izaera higroskopikoa eta hauskortasunagatik, hain zuzen. Horren ondorioz, aldaketa batzuk egin behar dira materiala erabilgarria lortzeko. Gauzak horrela, plastifikatzaileak beharrezkoak dira biopolimeroak prozesatzeko nahiz amaierako propietateak hobetzeko. Plastifikatzaileek, murriztu egiten dituzte hidrogeno-loturak, Van der Waals indarrak eta indar ionikoak bezalako kateen arteko elkarrekintzak, barne lubrifikatzaile gisa jokatuz. Gainera, plastifikatzaile-proteina lotura berriak sortzen dira eta haiei esker, murriztu egiten da biskositatea, eta erraztu egiten da molekulen mugimendua. Plastifikatzaileen artean, glizerola da ohikoena [4].

Biokonpositeen propietateak hobetzeko, kontuan izan behar dira bai gehigarriak bai eta polimeroa prozesatzeko metodoa. Soja-proteina isolatua, bi modu desberdinez prozesa daiteke. Alde batetik, prozesu hezea erabil daiteke, hau da, soluzioan gertatzen dena. Prozesu honetan proteina dispertsatuz eta disolbatzailea lurrunduz lortzen da filma. Bestalde, prozesu lehorra dago. Prozesu honetan, konpresio, injekzio edo estrusio metodo termomekanikoak erabiltzen dira. Azken urteotan, biokonpositeen garapenean aritu diren gehienek, soluzio eta konpresio metodoak erabili dituzte biokonpositeen prozesatze metodo gisa. Hala ere, estrusio eta injekzio bidezko 
moldeaketak dira industria mailan plastikoa prozesatzeko gehien erabiltzen diren metodoak $[6,7]$. Hori dela eta, material berri horien aplikazioak handi ditzake proteinetan oinarritutako biokonpositeak prozesatzeko estrusio eta injekzio metodoen erabiltzeak.

Hau guztia kontuan hartuta, lan honetan sakonean aztertu nahi ditugu biokonpositeen garapenerako estrusio eta injekzio bidezko prozesatze metodoak, soja-proteinan eta alga hondakin betegarrietan oinarrituak.

\section{NOLA KARAKTERIZATU PRESTATURIKO MATERIALAK?}

Lan honetan soja-proteina isolatua (SPI) erabili zen, ADM Protein Specialties Division-ek (Herbeherak) ekoiztutakoa. Glizerola plastifikatzaile gisa erabili zen eta Panreac (Espainia) enpresaren bidez eskuratu zen. Alga hondakina (AH), udazkenean erauzi zen Hondarribiko hondartzan bildutako $G e$ lidium sesquipedale (Rodophyta) alga gorritik eta betegarri gisa erabili zen.

Biokonpositeak prestatzeko, elkarrekin nahastu ziren SPI eta \% 30ko glizerola (proteinarekiko masa portzentaiaren arabera). AH gabeko lagin hau kontrol gisa erabili zen (AH0). SPI-aren ordez, masa portzentaiaren arabera, alga hondakinen pisuko \%3, \%6 eta \%9 portzentaian jarri ziren, eta AH3, AH6 eta AH9 izendatu ziren lortutakoak. Nahastea estrusio-makina batean sartu zen 250 bira/minutuko abiaduran. Estrusioan lortutako pelletak injekziorako makinan sartu ziren eta saiakuntzak egiteko finkatutako presioa eta tenperatura 450 bar-ekoa eta $120^{\circ} \mathrm{C}$-koa ziren, hurrenez hurren.

Entseatu aurretik, lagin guztiak $25{ }^{\circ} \mathrm{C}$-an eta $\% 50$ eko hezetasun erlatiboan egokitu ziren 48 orduz ganbera (ACS Sunrise $700 \mathrm{~V}$ ) batean. 5. irudian aurkezten dira biokonpositeen prestaketarako egin ziren prozesu guztiak.

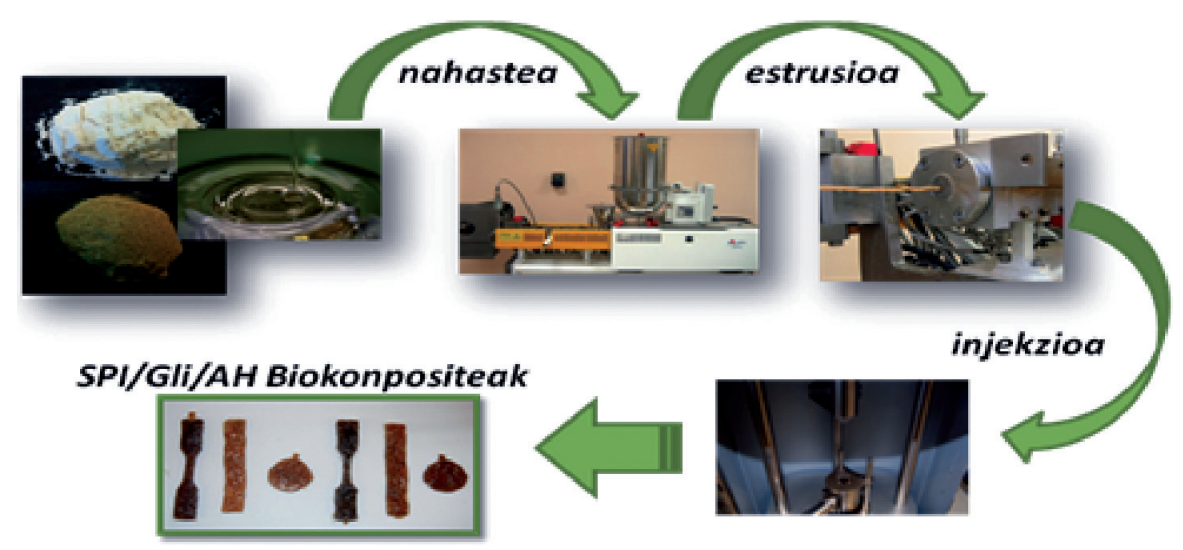

5. irudia. Biokonpositeak prestatzeko jarraitu diren pausoak. 
Materialen ur-lurrunaren iragazkortasuna (ULI) neurtzeko, tenperatura eta hezetasuna kontrolatzen dituen ganbera (PERME $\left.{ }^{\mathrm{TM}} \mathrm{W} 3 / 0120\right)$ erabili zen eta ASTM E96-00 araua jarraitu zen. Saiakuntza egiteko finkatutako tenperatura eta hezetasun erlatiboa $38{ }^{\circ} \mathrm{C}$-koa eta \%90ekoa izan ziren, hurrenez hurren. Hiru lagin neurtu ziren konposizio bakoitzeko.

Olioarekiko iragazkortasuna (OI) kalkulatzeko, laginak paperezko iragazkien gainean kokatu ziren eta olio tanta batzuk bota ziren biokonpositeen ertzak gailendu gabe. 24 ordu iragan ostean, laginak kendu eta iragazkiak berriz pisatu ziren. Hiru lagin neurtu ziren konposizio bakoitzeko.

Oxigenoaren transmisio-abiadura (OTA) neurtzeko, gas-iragazkortasunaren neurgailua (MOCON OX-TRAN 2/21) erabili zen eta ASTM D3985 araua jarraitu zen. Saiakuntza egiteko finkatutako tenperatura, presioa eta hezetasun erlatiboa $23{ }^{\circ} \mathrm{C}$-koa, $760 \mathrm{~mm} \mathrm{Hg}$-koa eta \%50ekoa izan ziren, hurrenez hurren. Hiru lagin neurtu ziren formulazio bakoitzeko.

Argiarekiko hesi-propietateak argi-transmitantzia neurtuz zehaztu ziren, 200 eta $600 \mathrm{~nm}$ bitarteko uhin-luzeretan, UV espektrofotometroa (UVJasco V-630) erabiliz. Hiru lagin errektangeluarrak moztu ziren biokonposite bakoitzeko.

Biokonpositeen kolorea neurtzeko makina mugikor bat erabili zen (CR-400 Minolta Croma Meter). Laginak plater zuri baten gainean jarri eta neurketak egiten ziren CIELAB kolore-eskala erabiliz. Kalibrazioa plater zuriarekiko egin zen. Neurketak hamar aldiz egin ziren biokonposite bakoitzeko eta kolore-desberdintasuna $\left(\Delta \mathrm{E}^{*}\right)$ kalkulatzeko, AH0 lagina erreferentzia gisa erabili zen.

Biokonpositeen distira $60^{\circ}$-ko angeluarekin neurtu zen distirametro batekin (Multi gloss 268 plus) eta ASTM D-523 araua jarraitu zen. Hamar lagin neurtu ziren formulazio bakoitzeko.

Datuei faktore bakar baten bariantza-analisia (ANOVA) egin zitzaien SPSS softwarea (SPSS Statistic 20.0) erabiliz. Post hoc konparaketa anitzak Tukey-ren froga anizkoitzaren bidez egin ziren, $\mathrm{P}<0,05$-eko esangura mailarekin.

\section{NOLAKOAK DIRA NEURTURIKO PROPIETATEAK?}

Biokonpositeen egonkortasuna ikertzeko, garrantzitsua da hesi-propietateen portaera aztertzea. Izan ere, olioarekiko iragazkortasuna, oxigenoaren transmisio-abiadura eta ur-lurrunarekiko iragazkortasuna neurtu ziren. Balioak 1. taulan erakusten dira. 
1. taula. Biokonpositeen olioarekiko iragazkortasuna (OI), oxigenoaren transmisio-abiadura (OTA) eta ur-lurrunarekiko iragazkortasuna (ULI) AH-ren funtzioan.

\begin{tabular}{cccc}
\hline Biokonpositeak & $\begin{array}{c}\text { OI } \\
(\%)\end{array}$ & $\begin{array}{c}\text { OTA } \\
\left(\mathrm{mL} / \mathrm{m}^{2} \text { egun }\right)\end{array}$ & $\begin{array}{c}\text { ULI } \\
\left(\mathrm{g} \mathrm{mm} / \mathrm{m}^{2} \mathrm{~h} \mathrm{kPa}\right)\end{array}$ \\
\hline AH0 & $0,38 \pm 0,02^{\mathrm{a}}$ & $<0,005$ & $2,9 \pm 0,3^{\mathrm{a}}$ \\
AH3 & $0,37 \pm 0,03^{\mathrm{a}}$ & $<0,005$ & $3,0 \pm 0,5^{\mathrm{a}}$ \\
AH6 & $0,38 \pm 0,01^{\mathrm{a}}$ & $<0,005$ & $3,0 \pm 0,4^{\mathrm{a}}$ \\
AH9 & $0,37 \pm 0,02^{\mathrm{a}}$ & $<0,005$ & $3,0 \pm 0,3^{\mathrm{a}}$ \\
\hline
\end{tabular}

a Zutabe berean letra bera duten bi balio ez dira esanguratsuki $(\mathrm{P}>0,05)$ desberdinak Tukeyren froga anizkoitzaren arabera.

Soja-proteinan oinarritutako biokonpositeek, lipidoen eta oxigenoaren kontrako hesi-propietate bikainak dituzte. Portaera hau SPI-aren ezaugarri hidrofilikoagatik gertatzen da. Gainera, soja-proteinan dauden aminoazido polarren portzentaia $\% 58 \mathrm{koa}$ da eta aminoazido hauek molekula ezpolarrak absorbatzea ekiditen dute. 6. irudian ikus daiteke AH3 biokonpositearen olioarekiko iragazkortasun ona.

(a)

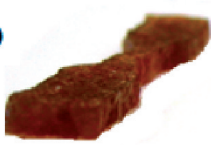

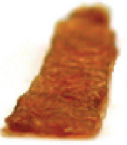

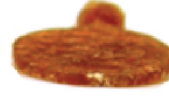

(b)

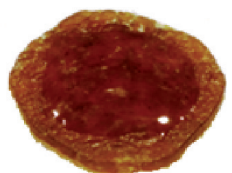

6. irudia. AH3 biokonpositeak duen (a) zimurtasuna eta (b) olioarekiko iragazkortasun ona.

Beste aldetik, prestatutako biokonpositeek oxigenoarekiko hesi-propietate hobeak dituzte ontzigintzan erabiltzen diren polimero sintetiko batzuek baino; esate baterako, polietilenoa (PE) edo polietilentereftalatoa (PET) baino balio hobeak dituzte [8,9]. Ur-lurrunarekiko iragazkortasunaren kasuan, balio altuak lortu ziren SPI-aren ezaugarri hidrofilikoaren ondorioz. Alga hondakina gehitzean berriz, osagaien arteko bateragarritasuna dela eta, hesi-propietateek ez zuten aldaketa esanguratsurik jasan $(\mathrm{P}>0,05)$.

Biokonpositeek duten UV argiarekiko erresistentzia neurtzeko, UV espektroskopia bidezko analisia erabili zen. Argi-transmisio balioak 7. irudian agertzen dira. SPI-an oinarritutako biokonpositeek, $200 \mathrm{~nm}$-tik $280 \mathrm{~nm}$-ra transmisio balio baxuak erakutsi zituzten, proteinan dauden zenbait kromoforo direla eta. Kromoforo hauek (tirosina, fenilalanina eta triptofanoa), gai dira $300 \mathrm{~nm}$-tik behera argia absorbatzeko [10]. Alga hondakina gehituta, hesi-propietate bikainak mantendu ziren. Orokorrean 


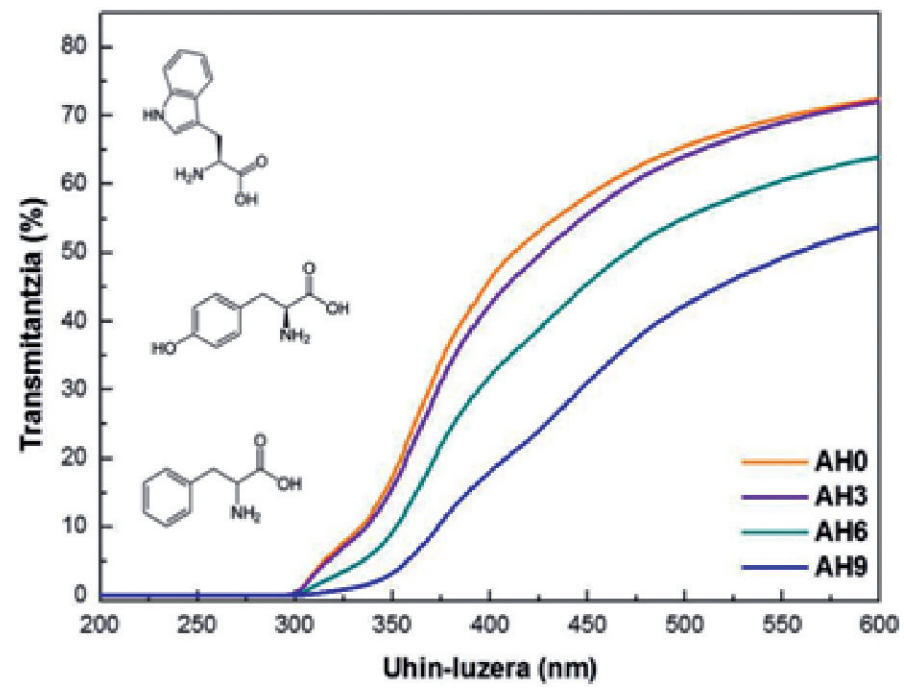

7. irudia. Biokonpositeen UV transmitantzia-kurbak AH-ren funtzioan.

biokonpositeek dituzten argiarekiko hesi-propietateak hobeak dira polipropilenoarenak (PP) edo polietilenoarenak (PE) baino [11]. Lortutako emaitzek, biokonpositeen prebentzio-ahalmena iradokitzen dute; izan ere, UV argiak sortutako produktuaren oxidazioa atzeratu lezakete.

Propietate optikoek nabarmen eragiten diote kanpoko itxurari. Hori dela eta, biokonpositeen kolorea eta distira aztertu ziren. Distira balioak 2. taulan agertzen dira. Gainazalak argia islatzeko duen ahalmena deskribatzen du distirak. Orokorrean, material batek $60^{\circ}$-ko distira balioa baldin badu, bere distira estandarra dela onartzen da [12]. Kasu honetan, biokonpositeen distira balio guztiak $30^{\circ}$-koak baino baxuagoak dira eta bat datoz laginek duten distira eskasarekin. Hala ere, distira zuzenki erlaziona daiteke gainazalak duen zimurtasunarekin, hau da, zimurtasuna handitu ahala, distira ere handituz doa [13]. Gauzak horrela, biokonpositeek inprimatzeko gainazal egokia dute, bere zimurtasun handiaren ondorioz. 5 irudian ikus daiteke AH3 biokonpositearen zimurtasuna zenbait laginetan.

2. taula. Biokonpositeen distira AH-ren funtzioan.

\begin{tabular}{ccccc}
\hline Biokonpositeak & AH0 & AH3 & AH6 & AH9 \\
\hline Distira $\left({ }^{\circ}\right)$ & $29,2 \pm 2,3^{\mathrm{a}}$ & $28,6 \pm 1,9^{\mathrm{a}}$ & $27,9 \pm 2,4^{\mathrm{a}}$ & $26,9 \pm 1,8^{\mathrm{a}}$ \\
\hline
\end{tabular}

a Letra bera duten bi balio ez dira esanguratsuki $(\mathrm{P}>0,05)$ desberdinak Tukeyren froga anizkoitzaren arabera. 
Koloreari dagokionez, alga hondakinaren berdetasunak eta soja-proteinaren horitasunak $\Delta \mathrm{E}^{*}$ balioei eragiten diete eta 8.irudian ikus daiteke.

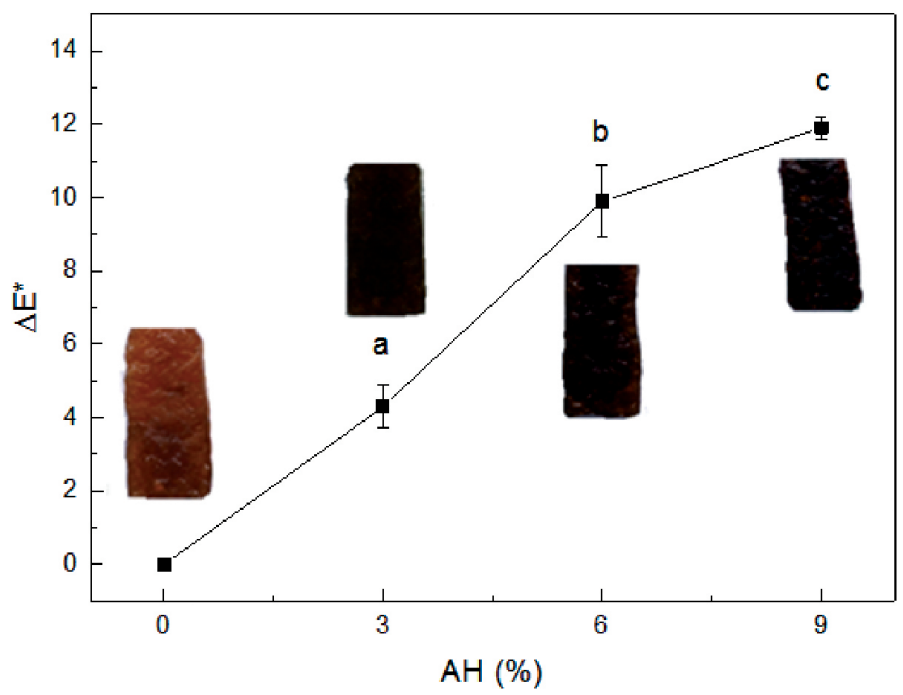

8. irudia. Biokonpositeen kolore-desberdintasuna $\left(\Delta \mathrm{E}^{*}\right) \mathrm{AH}-$ ren funtzioan.

${ }^{\mathrm{a}-\mathrm{c}}$ Letra bera duten bi balio ez dira esanguratsuki $(\mathrm{P}>0,05)$ desberdinak Tukeyren froga anizkoitzaren arabera.

\section{ONDORIOAK}

Soja-proteinazko pelletak estrusio metodoaren bidez lortu ziren eta biokonpositeak injekzio metodoaren bidez. Horren ondorioz, izugarri handitu ziren biokonposite hauek merkatura eramateko aukerak, laginak prozesatzeko erabilitako teknikak direlako plastikozko industrian erabiltzen diren metodo nagusiak. Bestalde, alga hondakina balioztatuta, hondakinen kantitatea eta materialen kostua murriztu egin ziren zen eta balio erantsizko produktuak sortu ziren. Lortutako biokonpositeen propietateei dagokienez, alga hondakinaren gehikuntzak ez zituen aldatu proteinan oinarritutako biokonpositeen hesi-propietate bikainak. Gainera, propietate optiko egokiek ere bere horretan jarraitu zuten.

\section{ESKER ONAK}

Tania Garridok EHUko Euskara Errektoreordetzari eskertu nahi dio, euskarazko tesia sustatzeko emandako diru-laguntza. Egileek Euskal He- 
rriko Unibertsitateari (UPV/EHU) eskertu nahi diote emandako diru-laguntza (GIU15/03 ikerketa-taldea). Beste horrenbeste Gipuzkoako Foru Aldundiari, proiektua egiteko emandako diru-laguntzagatik (OF221/2015 (ES)).

\section{BIBLIOGRAFIA}

[1] THE GLOBAL RISK REPORT. 2016. The new plastic economy: Rethinking the future of plastics. World economic forum, Switzerland.

[2] SIRACUSA, V., ROCCUli, P., ROMANI, S. eta DALlA ROSA, M. 2008.«Biodegradable polymers for food packaging: a review». Trends in Food Science \& Technology, 19, 634-643.doi:10.1016/j.tifs.2008.07.003

[3] HERNÁNDEZ-IZQUIERDO, V.M. eta KROCHTA, J.M. 2008.«Thermoplastic processing of proteins for film formation: a review». Journal of Food Science, 73, 30-39.doi: 10.1111/j.1750-3841.2007.00636.x

[4] TIAN, H., WU, W., GUO, G., GAOLUN, B., JIA, Q. eta XIANG, A. 2012.«Microstructure and properties of glycerol plasticized soy protein plastics containing castor oil». Journal of Food Engineering, 109, 496-500. doi:10.1016/j.jfoodeng.2011.10.033

[5] ATEF, M., REZAEI, M. eta BEHROOZ, R. 2011. «Characterization of physical, mechanical, and antibacterial properties of agar-cellulose bionanocomposite films incorporated with savory essential oil». Journal of Food Engineering, 107, 21-26.doi:10.1016/j.foodhyd.2014.09.037

[6] ZARINA, S. eta AHMAD, I. 2015.«Biodegradable composite films based on k-carrageenan reinforced by cellulose nanocrystal from kenaffibers». Bioresources, 10, 256-271.

[7] LAGRAIN, B., GODERIS, B., BRIJS, K. eta DELCOUR, J.A. 2010.«Molecular basis of processing wheat gluten toward biobased materials». Biomacromolecules, 11, 533-541.doi:10.1021/bm100008p

[8] NORRAHIM, M.N.F., ARIFFIN, H., HASSAN, M.A., IBRAHIM, N.A. eta NISHIDA, H. 2013.«Performance evaluation and chemical recyclability of a polyethyelene/poly(3-hydroxybutyrate-co-3-hydroxyvalerate) blend for sustainable packaging». RSC Advances, 3, 24378-24388.doi:10.1039/ C3RA43632B

[9] SIRÓ, I., PLACKETT, D. eta SOMMER-LARSEN, P. 2010.«A comparative study of oxygen transmission rates through polymer films base on fluorescence quenching». Packaging Technology and Science, 23, 301-315. doi: $10.1002 /$ pts.895

[10] LI, H., LIU, B.L., GAO, L.Z. eta CHEN, H.L. 2004.«Studies on bullfrog skin collagen». Food Chemistry, 84, 65-69.doi:10.1016/S03088146(03)00167-5

[11] JAKOBSEN, M., JESPERSEN, L., JUNCHER, D., BECKER, E.M. eta RISBO, J. 2005.«Oxygen and light barrier properties of thermoformed packaging materials used for modified atmosphere packaging. Evaluation of per- 
formance under realistic storage conditions».Packaging Technology and Science, 18, 265-272.doi:10.1002/pts.697

[12] ATARÉS, L., DE JESÚS, C., TALENS, P. eta CHIRALT, A. 2010. «Characterization of SPI based edible films incorporated with cinnamon or ginger essential oils». Journal of Food Engineering, 99, 384-391.doi:10.1016/j. jfoodeng.2010.03.004

[13] VILLALOBOS, R., CHANONA, J., HERNANDEZ, P., GUTIERREZ, G. eta CHIRALT, A. 2005.«Gloss and transparency of hydroxypropyl methylcellulose films containing surfactants as affected by their microstructure». Food Hydrocolloids, 19, 53-61.doi:10.1016/j.foodhyd.2004.04.014 